\title{
Metabolic Syndrome - Community Nursing Evaluation and Intervention: the CroHort Study
}

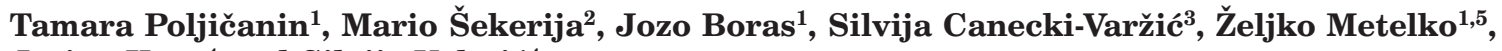 \\ Josipa Kern ${ }^{4}$ and Silvije Vuletić ${ }^{4}$ \\ ${ }^{1}$ University of Zagreb, Merkur University Hospital, Vuk Vrhovac University Clinic, Zagreb, Croatia \\ ${ }^{2}$ Croatian National Institute of Public Health, Zagreb, Croatia \\ 3 „J. J. Strossmayer« University, Osijek University Hospital Center, Osijek, Croatia \\ ${ }^{4}$ University of Zagreb, School of Medicine, "Andrija Štampar« School of Public Health, Zagreb, Croatia \\ ${ }^{5}$ University of Zagreb, School of Medicine, Zagreb, Croatia
}

\begin{abstract}
A B S T R A C T
This prospective study of 1277 participants investigated patient risk self-assessment, motivation for changes in main determinants of the metabolic syndrome and the impact of community nursing intervention on cardiovascular risk reduction. Observed values of metabolic syndrome determinants indicated an elevated cardiovascular risk. Participants showed greatest motivation for positive changes regarding blood pressure, (3.70 \pm 1.26$)$ then hyperglycemia (3.55 \pm 1.28$)$,

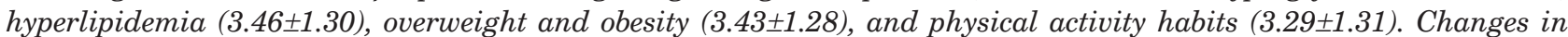
physical activity and nutritional habits were not related to self-reported motivation regardless of the age and sex ( $p>0.05$ ). The most pronounced median improvements were observed in cholesterol (men 4.43\%, women 4.89\%) and triglycerides (men $3.41 \%$, women 1.49\%), with only slight changes in BMI (men 1.08\%, women 1.18\%) and no change in waist-to-hip ratio and glucose. This study revealed that, although aware and motivated, patients often do not succeed in changing habits. Concomitant changes of the environment and multisectoral prevention approach is necessary.
\end{abstract}

Key words: metabolic syndrome, prevention, cardiovascular disease, community nursing intervention, CroHort study

\section{Introduction}

Metabolic syndrome is a group of risk factors and disorders that greatly increases the risk of developing diabetes, kidney and cardiovascular diseases ${ }^{1}$. Regardless of the diagnostic criteria used (International Diabetes Federation (IDF), World Health Organization (WHO) or National Cholesterol Education Program Adult Treatment Panel III (NCEP III)), there are four main elements of the metabolic syndrome: abdominal obesity, dyslipoproteinemia, hypertension and diabetes mellitus or pre-diabetes, all being the consequences of insulin resistance and compensatory hyperinsulinemia ${ }^{2}$.

It has been estimated that a quarter of the world's adults have metabolic syndrome, although the prevalence of the syndrome within individual cohorts varies with the definition used ${ }^{3-5}$. Within each definition, the prevalence of the metabolic syndrome increases with age and varies with sex and ethnicity ${ }^{3}$.
In Croatia it has been estimated that $38-39 \%$ of women and 26-28\% of men have metabolic syndrome with differences that depend on the region and the criteria used, i.e. WHO criteria ${ }^{6}$ or modified NCEP III criteria $^{7}$, while with NCEP III criteria those proportions rise to almost $85 \%$ in men and $72 \%$ in women in the Baranja region 6 .

Since the metabolic syndrome is an important risk factor for cardiovascular disease incidence and mortality, as well as for all-cause mortality, the detection, prevention, and treatment of its underlying risk factors should become an important approach in the reduction of the cardiovascular disease burden in the general population ${ }^{8}$.

Still, it is currently not clear how to implement preventive interventions into clinical practice, but it is clear that the intervention requires an integrated and trans- 
disciplinary approach ${ }^{9}$. However, metabolic syndrome is frequently unrecognized, especially in the overweight and obese individuals ${ }^{10}$, and the beginning of changes should therefore be proper recognition of risk factors by both health care professionals and patients themselves.

The aim of this study was to evaluate patients' self-assessment of risks and their motivation for lifestyle changes, i.e. changes in the main determinants of the metabolic syndrome. Furthermore, community nurses carried out a simultaneous intervention aimed at changing the participants' lifestyle to reduce their cardiovascular risks and improve their health in general.

\section{Patients and Methods}

This study was a part of the Croatian Adult Health Cohort Study (CroHort), a repeated cross-sectional survey of adults aimed at providing a comprehensive community health assessment of Croats, including their access to and use of health care services, health status, and determinants of health such as nutrition, physical activity, smoking and alcohol consumption. The first survey was conducted in $2003^{11}$ and the second one in $2008^{12}$. A sub-sample for community nursing assessment and intervention was selected according to respondents' willingness to participate and nurses' motivation to perform an additional study in their region.

The community nursing study included 1277 participants. Baseline assessment combined an interview and determination of the following parameters: anthropometric measures (body weight, body mass, waist and hip circumference), body mass index and waist-to-hip ratio, systolic and diastolic blood pressure, and glucose and lipid fractions. Social and health status as well as self-evaluation of lifestyle modifications from 2003 were assessed. Glucose and lipid measurements were performed with Accu-Chek blood glucose/cholesterol monitoring device; Roche Diagnostics, 2008. After the initial interview participants were asked to assess their risks and evaluate their motivation to change. Community nurses counseled them individually and defined their specific goals based on the insight into their risks and current habits. The follow-up visit after one year again included anthropological measures (body weight, body mass, waist and hip circumference), an assessment of body mass index, waist-to-hip ratio, systolic and diastolic blood pressure, and glucose and lipid fractions.

\section{Statistical methods}

All statistical analyses were performed using SAS (version 9.1.3). Variance homogeneity was tested by Lindman's test prior to the analysis of correlation and between-group differences. Normality of distribution was tested by using Shapiro-Wilks' W-test. Differences in independent variables between the groups were analyzed using t-test for unequal variances, Mann-Whitney U-test (for two groups) and ANOVA (for three or more groups). Wilcoxon matched pairs test was used to determine differences between initial and final values while differ- ences in the prevalence of individual conditions were tested using $\mathrm{chi}^{2}$ test. The level of significance of correlation between variables and the correlation trend were analyzed by Spearman Rank Order Correlation Test. Backward-stepwise logistic regression was used for the prediction of the probability of occurrence of an event from explanatory variables. Statistical significance was set at $\alpha=0.05$ in all analyses.

\section{Results}

The study included 1277 participants, 572 men (44.79\%) and 705 women $(55.21 \%)$ of mean age $61.55 \pm 16.52$ years.

Waist-to-hip ratio and diastolic blood pressure (DBP) were significantly higher in men than in women $(0.96 \pm$ 0.11 vs. $0.89 \pm 0.11 ; \mathrm{p}<0.001$ and $82.76 \pm 11.75$ vs. $80.46 \pm$ $10.72 ; \mathrm{p}<0.001$ ) while total cholesterol was significantly higher in women than men $(5.51 \pm 1.22$ vs. $5.29 \pm 1.07$; $\mathrm{p}=0.015$ ). There were no statistically significant differences in age, BMI, systolic blood pressure (SBP), fasting glucose and triglycerides between sexes.

Mean values and standard deviations (SD) of the measurements and metabolic parameters on baseline visit according to gender are presented in Table 1 .

Depending on their self-evaluation of the risk of hypertension, diabetes and hyperlipidemia the patients were divided into eight groups. BMI, waist-to-hip ratio, systolic blood pressure, diastolic blood pressure, fasting glucose, total cholesterol and triglyceride levels were assessed in both sexes. Values of the investigated parameters depending on the existing risks are presented in Table 2.

Between the patients with an existing risk or multiple risks and those without them, statistically significant differences were observed in all studied parameters in both men and women (ANOVA, $\mathrm{p}<0.001$ ), except for the waist-to-hip ratio in men, which did not differ significantly (ANOVA, $p=0.111$ ). Levels were highest with all existing risks and decreased as the number of risks decreased.

TABLE 1

BASELINE CHARACTERISTICS OF THE INVESTIGATED POPULATION ACCORDING TO SEX

\begin{tabular}{|c|c|c|c|c|c|}
\hline & \multicolumn{2}{|c|}{ Men } & \multicolumn{2}{|c|}{ Women } & \multirow{2}{*}{ p-value } \\
\hline & $\overline{\mathrm{X}}$ & $\mathrm{SD}$ & $\overline{\mathrm{X}}$ & $\mathrm{SD}$ & \\
\hline Age (years) & 60.61 & 15.88 & 61.80 & 16.70 & 0.517 \\
\hline $\mathrm{BMI}\left(\mathrm{kg} / \mathrm{m}^{2}\right)$ & 28.10 & 4.79 & 27.92 & 5.25 & 0.526 \\
\hline Waist/hip & 0.96 & 0.11 & 0.89 & 0.11 & 0.000 \\
\hline $\mathrm{SBP}(\mathrm{mmHg})$ & 139.30 & 20.14 & 137.03 & 21.51 & 0.055 \\
\hline DBP (mmHg) & 82.76 & 11.75 & 80.46 & 10.72 & 0.000 \\
\hline Glucose $(\mathrm{mmol} / \mathrm{L})$ & 6.60 & 2.37 & 6.55 & 2.52 & 0.733 \\
\hline Cholesterol (mmol/L) & 5.29 & 1.07 & 5.51 & 1.22 & 0.015 \\
\hline Triglycerides $(\mathrm{mmol} / \mathrm{L})$ & 2.17 & 1.25 & 2.08 & 1.33 & 0.396 \\
\hline
\end{tabular}


TABLE 2

RISK FACTORS ACCORDING TO THE SELF-EVALUATION OF THE RISK OF HYPERTENSION, DIABETES MELLITUS AND HYPERLIPIDEMIA

\begin{tabular}{|c|c|c|c|c|c|c|c|c|}
\hline \multicolumn{9}{|l|}{ A) Men } \\
\hline Hypertension & risk & risk & risk & risk & no risk & no risk & no risk & no risk \\
\hline Diabetes mellitus & risk & risk & no risk & no risk & risk & risk & no risk & no risk \\
\hline Hyperlipidemia & risk & no risk & risk & no risk & risk & no risk & risk & no risk \\
\hline $\mathrm{BMI}-\overline{\mathrm{X}}$ & 31.03 & 28.85 & 29.56 & 28.14 & 30.35 & 28.74 & 27.56 & 26.63 \\
\hline $\mathrm{BMI}-\mathrm{SD}$ & 6.99 & 4.56 & 4.66 & 4.25 & 7.01 & 5.04 & 4.25 & 4.22 \\
\hline Waist/hip $-\overline{\mathrm{X}}$ & 0.99 & 0.99 & 0.97 & 0.96 & 0.96 & 0.95 & 0.95 & 0.94 \\
\hline Waist/hip - SD & 0.10 & 0.10 & 0.09 & 0.07 & 0.05 & 0.08 & 0.10 & 0.12 \\
\hline $\mathrm{SBP}-\overline{\mathrm{X}}$ & 154.36 & 148.39 & 151.94 & 150.84 & 131.42 & 132.46 & 128.80 & 130.77 \\
\hline SBP - SD & 20.67 & 20.95 & 18.36 & 22.73 & 11.66 & 19.72 & 10.86 & 14.01 \\
\hline $\mathrm{DBP}-\overline{\mathrm{X}}$ & 90.64 & 83.75 & 88.15 & 89.75 & 72.50 & 77.86 & 77.78 & 79.68 \\
\hline $\mathrm{DBP}-\mathrm{SD}$ & 12.63 & 14.05 & 8.80 & 14.86 & 7.23 & 10.99 & 8.45 & 7.68 \\
\hline Glucose $-\bar{X}$ & 7.80 & 8.68 & 5.97 & 5.86 & 8.98 & 8.28 & 6.01 & 5.77 \\
\hline Glucose - SD & 2.31 & 3.29 & 0.86 & 1.92 & 2.90 & 2.14 & 2.03 & 1.19 \\
\hline Cholesterol - $\overline{\mathrm{X}}$ & 5.69 & 4.92 & 5.83 & 4.87 & 5.88 & 4.75 & 5.62 & 5.01 \\
\hline Cholesterol - SD & 0.90 & 0.51 & 1.18 & 0.92 & 1.15 & 0.98 & 1.03 & 0.97 \\
\hline Triglycerides $-\overline{\mathrm{X}}$ & 2.95 & 2.03 & 2.62 & 1.65 & 2.45 & 2.00 & 2.57 & 1.69 \\
\hline Triglycerides - SD & 1.40 & 1.22 & 1.55 & 0.62 & 1.18 & 0.51 & 1.46 & 0.82 \\
\hline \multicolumn{9}{|l|}{ b) Women } \\
\hline Hypertension & risk & risk & risk & risk & no risk & no risk & no risk & no risk \\
\hline Diabetes melitus & risk & risk & no risk & no risk & risk & risk & no risk & no risk \\
\hline Hyperlipidemia & risk & no risk & risk & no risk & risk & no risk & risk & no risk \\
\hline $\mathrm{BMI}-\overline{\mathrm{X}}$ & 30.31 & 29.97 & 28.72 & 27.78 & 30.80 & 27.40 & 28.19 & 26.01 \\
\hline BMI - SD & 4.18 & 5.22 & 4.48 & 5.03 & 7.99 & 3.95 & 4.46 & 4.12 \\
\hline Waist/hip $-\overline{\mathrm{X}}$ & 0.91 & 0.93 & 0.91 & 0.89 & 0.88 & 0.91 & 0.87 & 0.87 \\
\hline Waist/hip - SD & 0.08 & 0.16 & 0.10 & 0.10 & 0.10 & 0.10 & 0.09 & 0.11 \\
\hline $\mathrm{SBP}-\overline{\mathrm{X}}$ & 147.41 & 157.95 & 144.42 & 151.85 & 124.59 & 134.81 & 126.40 & 125.80 \\
\hline SBP - SD & 20.93 & 16.69 & 20.70 & 20.72 & 9.63 & 20.42 & 17.16 & 14.60 \\
\hline $\mathrm{DBP}-\overline{\mathrm{X}}$ & 82.19 & 87.73 & 86.03 & 86.85 & 76.50 & 76.65 & 75.81 & 75.46 \\
\hline $\mathrm{DBP}-\mathrm{SD}$ & 9.60 & 9.08 & 9.93 & 10.98 & 6.76 & 10.12 & 10.37 & 7.98 \\
\hline Glucose $-\overline{\mathrm{X}}$ & 9.16 & 10.00 & 5.84 & 5.91 & 7.53 & 8.20 & 5.44 & 5.39 \\
\hline Glucose - SD & 3.68 & 3.32 & 1.25 & 2.21 & 1.95 & 2.87 & 0.54 & 0.92 \\
\hline Cholesterol $-\overline{\mathrm{X}}$ & 5.92 & 5.27 & 6.24 & 5.15 & 5.92 & 4.99 & 6.24 & 4.84 \\
\hline Cholesterol - SD & 0.99 & 1.18 & 1.00 & 0.93 & 0.98 & 0.99 & 1.27 & 1.03 \\
\hline Triglycerides $-\overline{\mathrm{X}}$ & 2.56 & 2.10 & 2.22 & 1.78 & 3.25 & 2.26 & 2.78 & 1.45 \\
\hline Triglycerides - SD & 1.41 & 0.82 & 1.20 & 0.96 & 2.22 & 1.54 & 1.87 & 0.54 \\
\hline
\end{tabular}

In order to evaluate successfulness in previous lifestyle changes, nutritional and physical activity habits from 2003 and 2008 were analyzed. The analysis revealed that the majority of participants did not change their habits at all in the period preceding nursing evaluation; on the contrary, in part of the investigated population they even worsened. Only $10 \%$ of men and $5.63 \%$ of women improved their nutritional habits significantly and $9.12 \%$ of men and $4.35 \%$ of women improved their physical activity. Changes in habits were more frequently achieved by men than women in nutrition (chi-square $=$
8.85, $\mathrm{df}=2, \mathrm{p}=0.012)$ and physical activity (chi-square $=$ $11.2, \mathrm{df}=2, \mathrm{p}=0.004)$. Self-evaluation of the lifestyle changes from 2003 till 2008 , i.e. in the period preceding the nursing assessment, are shown in Figure 1.

Nursing assessment also included evaluation of current motivation of participants. They self-evaluated their motivation with scores ranging from 1 to 5,1 indicating the lowest possible motivation and 5 the greatest motivation. The analysis revealed greatest motivation for positive changes that affected blood pressure $(3.70 \pm 1.26)$ as compared to those affecting hyperglycemia (3.55 \pm 1.28 ), 


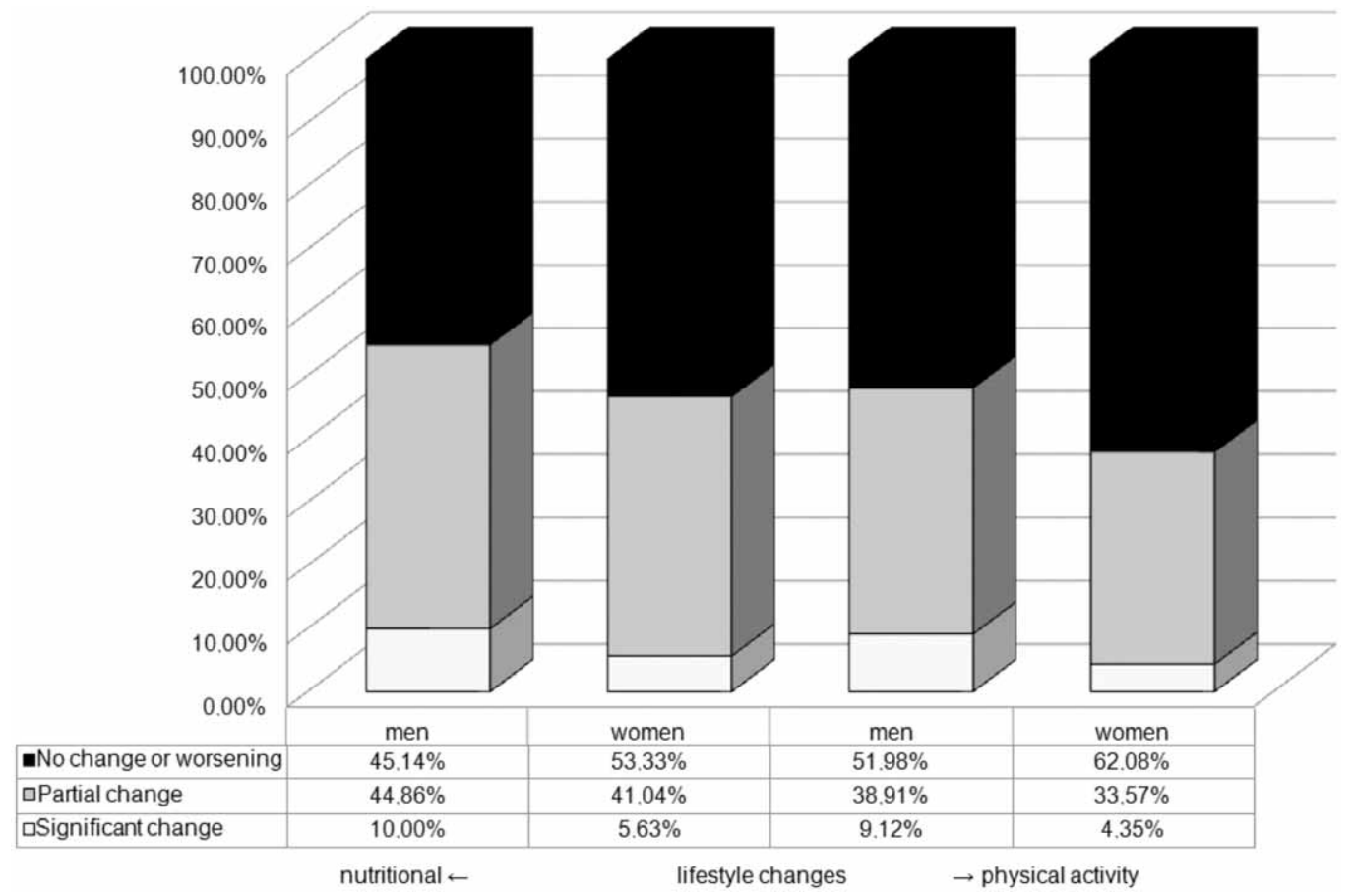

Fig. 1. Self-evaluation of lifestyle changes in the period between 2003 and 2008.

hyperlipidemia (3.46 \pm 1.30$)$, overweight or obesity $(3.43 \pm$ 1.28 ), while the lowest motivation was expressed for changing physical activity habits (3.29 \pm 1.31$)$. Although motivation of the participants was good and in some aspects even very good, median changes during intervention were not as expected. Improvements in the main parameters compared to the baseline values (1-post interventional value/ baseline value) are presented in Table 3 .

During the intervention the most pronounced changes were observed in cholesterol and triglyceride levels, while changes in BMI values in both sexes were only minor. Participants in general were least successful in changing their waist-to-hip ratio and glucose, median difference being zero in both sexes. There were no statistically significant differences in the improvements between the sexes (all p's >0.05)

Backward-stepwise logistic regression was used for the prediction of the probability of changes vs. motivation for changes in risk factors related to overweight/obe- sity, hypertension, hyperlipidemia and physical activity. There were no statistically significant predictors of changes, i.e. changes in physical activity $(p=0.758)$ and nutritional habits $(p=0.393)$ were not related to the self-reported motivation of participants regardless of their age and sex.

\section{Discussion and Conclusion}

The results of this study revealed high values of the main determinants of the metabolic syndrome in the investigated population with mean values of BMI, waist/ hip ratio, glucose, cholesterol and triglycerides above the desirable and currently recommended values ${ }^{13-16}$, i.e. in a range that can be correlated with an elevated risk of further cardiovascular disease development. This is in agreement with the published studies reporting on a high proportion of examinees with obesity in developed world ${ }^{17}$, elevated glucose or cholesterol and a high proportion of

TABLE 3

IMPROVEMENTS IN MAIN METABOLIC PARAMETERS DURING NURSING INTERVENTION ACCORDING TO SEX

\begin{tabular}{|c|c|c|c|c|c|c|c|}
\hline \multirow{2}{*}{ Difference } & \multicolumn{3}{|c|}{ Men } & \multicolumn{3}{|c|}{ Women } & \multirow{2}{*}{$\mathrm{p}$} \\
\hline & Median & Minimum & Maximum & Median & Minimum & Maximum & \\
\hline $\mathrm{BMI}$ & $1.08 \%$ & $-47.35 \%$ & $51.07 \%$ & $1.18 \%$ & $-39.85 \%$ & $58.89 \%$ & 0.952 \\
\hline Waist/hip & $0.00 \%$ & $-65.87 \%$ & $46.22 \%$ & $0.00 \%$ & $-142.91 \%$ & $52.14 \%$ & 0.099 \\
\hline Glucose & $0.00 \%$ & $-327.59 \%$ & $59.04 \%$ & $0.00 \%$ & $-147.06 \%$ & $64.82 \%$ & 0.406 \\
\hline Cholesterol & $4.43 \%$ & $-308.00 \%$ & $79.61 \%$ & $4.89 \%$ & $-385.44 \%$ & $74.65 \%$ & 0.952 \\
\hline Triglycerides & $3.41 \%$ & $-293.00 \%$ & $89.38 \%$ & $1.49 \%$ & $-344.44 \%$ & $90.00 \%$ & 0.240 \\
\hline
\end{tabular}


undiagnosed patients ${ }^{18}$, as well as on low effective medication coverage for their control ${ }^{19}$ However, in our study only mean blood pressure values were in high normal range. A good thing is that the highest levels were observed in the participants who at least recognized their risk better and decreased with the reduction of risks that the participants were aware of.

The majority of participants did not change their habits in the period preceding nursing evaluation at all, which leads to a conclusion that standard, routine education and counseling provided within clinical care and public health interventions are not very efficient in this population. The results obtained revealed that with the existing standards of health interventions lifestyle modification can be expected only in a minority of population.

Although aware of the risks and motivated, the participants were unsuccesful in changing habits and determinants of the metabolic syndrome as well as the degree of obesity, and when changes finally occurred, motivation was not shown to be a predictor. This may be due to an approach that is less intensive and comprehensive than that in the studies of the impact of lifestyle intervention, i.e. on the development of diabetes ${ }^{20,21}$. Recent studies have also raised the problem of the transfer of compre-

\section{R E F E R E N C E S}

1. REYNOLDS K, HE J, Am J Med Sci, 330 (2005) 273. — 2. PAVLIĆ-RENAR I, POLJIčANIN T, METELKO Ž, Acta Med Croat, 61 (2007) 335. - 3. DAY C, Diab Vasc Dis Res, 4 (2007) 32. - 4. CAMERON AJ, SHAW JE, ZIMMET PZ, Endocrinol Metab Clin North Am, 33 (2004) 351. - 5. LAAKSONEN DE, NISKANEN L, LAKKA HM, LAKKA TA, UUSITUPA M, Ann Med, 36 (2004) 332. - 6. TUCAK-ZORIĆ S, BILIĆ ČURČIĆ I, MIHALJ H, DUMANČIĆ I, ZELIĆ Ž, MAJETIĆ CETINA N, SMOLIĆ R, VOLAREVIĆ M, MISSONI S, TOMLJENOVIĆ A, SZIROVICZA L, DURAKOVIĆ Z, XI H, CHAKRABORTY R, DEKA R, TUCAK A, RUDAN P, Coll Antropol, 32 (2008) 615. - 7. KOLČIĆ I, VORKO-JOVIĆ A, SALZER B, SMOLJANOVIĆ M, KERN J, VULETIĆ S, Croat Med J, 47 (2006) 585. — 8. GALASSI A, REYNOLDS K, HE J, Am J Med, 119 (2006) 812. - 9. SCHWARZ PE, REIMANN M, LI J, BERGMANN A LICINIO J, WONG ML, BORNSTEIN SR, Horm Metab Res, 39 (2007) 777. - 10. BO S, CICCONE G, PEARCE N, MERLETTI F, GENTILE L, CASSADER M, PAGANO G, Diabetes Res Clin Pract, 75 (2007) 362 . 11. VULETIĆ S, POLAŠEK O, KERN J, STRNAD M, BAKLAIĆ Ž, Coll Antropol, 33 Suppl. 1 (2009) 3. - 12. IVIČEVIĆ-UHERNIK A, VULETIĆ S, KERN J, DEĆKOVIĆ-VUKRES V, MIHEL S, ERCEG M, PRISTAŠA I, Coll Antropol 36 (2012) suppl 1. 3. - 13. WHO, BMI classification, WHO Global Database on Body Mass Index, accessed 21.6.2011. Available from: URL: http://apps.who.int/bmi/index.jsp?introPage=intro $3 . h t m l-14$. NATIONAL HEART, LUNG, AND BLOOD INSTITUTE, Executive Summary of the Third Report of the National Cholesterol Education Program (NCEP) Expert Panel on Detection, Evaluation, and Treatment of hensive interventions to daily routine $\mathrm{e}^{22,23}$ and concerns about their effectiveness in that environment.

From the literature we know that prevention of the metabolic syndrome should start as early as possible, involve all age groups ${ }^{24}$ and be based on lifestyle changes. However, how best to promote lifestyle changes is not clear yet and all efforts to control obesity, increase physical activity and improve compliance with current dietary recommendations should be continued ${ }^{4}$.

This study is a first step in the right direction, but future success of interventions requires alocation of the resources to interventions tailored for the average Croatian citizen. Concomitant changes of the environment and multisectorial approach to prevention and treatment are essential, as without that no significant positive trend on the population level can be expected.

\section{Acknowledgements}

The authors wish to thank all their colleagues from the extended CASH and CroHort team and prof. L. Perkovic for editing this manuscript. The manuscript was prepared within the project of the Ministry of Science, Education and Sports, Grant No. 108-1080135-0264 .

High Blood Cholesterol in Adults (Adult Treatment Panel III), accessed 21.6.2011. Available from: URL: http://www.nhlbi.nih.gov/guidelines/cholesterol/atp3xsum.pdf. - 15. MILLER M, STONE NJ, BALLANTYNE C, BITTNER V, CRIQUI MH, GINSBERG HN, GOLDBERG AC, HOWARD WJ, JACOBSON MS, KRIS-ETHERTON PM, LENNIE TA, LEVI M, MAZZONE T, PENNATHUR S, Circulation, 123 (2011) 2292. - 16. WHO, Definition, diagnosis and classification of diabetes mellitus and its complications. Report of a WHO consultation. Part 1: diagnosis and classification of diabetes of mellitus. WHO/NCD/NCS/99.2. Geneva: World Health Organization, 1999 - 17. SEIDELL JC, Horm Metab Res, 29 (1997) 155. — 18. IDF, Global guideline for type 2 diabetes. Brussels: International Diabetes Federation; 2005, accessed 21.6.2011. Available from: URL: http://www.idf.org/node/ 1285? unode $=$ B7462CCB-3A4C-472C-80E4- 710074D74AD3 - 19. ROTH GA, FIHN SD, MOKDAD AH, AEKPLAKORN W, HASEGAWA T, LIM SS, Bulletin of the World Health Organization, 89 (2011) 92. - 20. LINDSTRÖM J, LOUHERANTA A, MANNELIN M, RASTAS M, SALMINEN V, ERIKSSON J, UUSITUPA M, TUOMILEHTO J, Diabetes Care, 26 (2003) 3230 - 21. KNOWLER WC, BARRETT-CONNOR E, FOWLER SE, HAMMAN RF, LACHIN JM, WALKER EA, NATHAN DM, N Engl J Med, 346 (2002) 393. — 22. KATULA JA, VITOLINS MZ, ROSENBERGER EL, BLACKWELL CS, MORGAN TM, LAWLOR MS, GOFF DC JR, Diabetes Care, (2011) (ahead of print). - 23. CARDONA-MORRELL M, RYCHETNIK L, MORRELL SL, ESPINEL PT, BAUMAN A, BMC Public Health, 29 (2010) 653. — 24. MIŠIGOJ DURAKOVIĆ M, DURAKOVIĆ Z, Coll Antropol, 33 (2009) 759.

\section{T. Poljičanin}

University of Zagreb, Merkur University Hospital, Zajčeva 19, 10000 Zagreb, Croatia e-mail: Tamara.Poljicanin@idb.hr 


\section{METABOLIČKI SINDROM - EVALUACIJA I INTERVENCIJA PATRONAŽNE SLUŽBE: CROHORT STUDIJA}

\section{S A Ž E T A K}

Ovo longitudinalno istraživanje ispitivalo je samoprocjenu rizika i motiviranost bolesnika za promjene glavnih odrednica metaboličkog sindroma, kao i učinak intervencije patronažnih sestara na smanjenje kardiovaskularnih rizika. Obuhvaćeno je 1277 ispitanika Hrvatske zdravstvene ankete iz 2008. g. Praćenje je uključivalo analizu dobi, indeksa tjelesne težine, omjera struka i bokova, sistoličkog i dijastoličkog tlaka te glukoze i lipidnih frakcija, dok su socijalni i zdravstveni status, samoprocjena promjena životnih navika od 2003. g. i motiviranost za daljnje promjene procijenjeni intervjuom. Utvrđene su visoke vrijednosti glavnih odrednica metaboličkog sindroma koje ukazuju na povišen rizik razvoja kardiovaskularnih bolesti. Ispitanici sa svim promatranim rizicima imali su najviše vrijednosti parametara, a sa smanjivanjem broja prisutnih rizika opadale su i vrijednosti promatranih parametara u oba spola $(\mathrm{p}<0,001)$, izuzev omjera struka i bokova koji se u muškaraca nije značajno razlikovao $(\mathrm{p}=0,111)$. Ispitanici su pokazali veću motiviranost za pozitivne promjene povezane s krvnim tlakom $(3,70 \pm 1,26)$ no s hiperglikemijom $(3,55 \pm 1,28)$, hiperlipidemijom $(3,46 \pm 1,30)$, prekomjernom tjelesnom težinom i debljinom $(3,43 \pm 1,28)$, a najniža je motivacija bila povezana s promjenama u tjelesnoj aktivnosti $(3,29 \pm 1,31)$. Promjene $u$ tjelesnoj aktivnosti $(p=0,758)$ i prehrani $(p=0,393)$ nisu bile povezane s motivacijom bolesnika bez obzira na spol. Najizraženije promjene (srednja vrijednost) opažene su u vrijednostima kolesterola (muškarci 4,43\%, žene 4,89\%) i triglicerida (muškarci 3,41\%, žene 1,49\%), dok su promjene u indeksu tjelesne mase bile slabije izražene (muškarci 1,08\%, žene 1,18\%), a srednja vrijednost promjene omjera struka i bokova kao i vrijednosti glukoze bila je nula. Ovim ispitivanjem dokazano je da, iako osviješteni i motivirani, bolesnici često ne uspijevaju promijeniti životne navike i glavne odrednice metaboličkog sindroma. Ako se promjene naposlijetku i dogode, motivacija im nije pretkazatelj. Istovremene promjene okruženja i multisektorski pristup prevenciji i liječenju vjerojatno su neizostavni na populacijskoj razini. 